\title{
WHERE WERE BRADSHAW'S 900 WESTERN GREBE NESTS?
}

\section{STUART HOUSTON, 863 University Drive, Saskatoon, Saskatchewan S7N 0]8}

Fred Bradshaw published in the Oologist in 1929, the following short note titled "From Saskatchewan:"

"Last year [1928] [I] found what to me was an unusual colony of Western Grebes. Ninety-five per cent of nests were in open water. This year [1929] I visited the same spot and the lake is much lower. The old nests are all on dry land now and by actual count there were over 900 nests. These Grebes apparently are late breeders for the birds were in the water around the old site on June 5th and apparently had not yet started to build their nests. Last year [1928] on July 4th I waded through the nests and found only one young bird. I thought perhaps the first nests had been destroyed, but am now inclined to the opinion they are late breeders. The solid gray down of the young with reddish patch on the crown combine to make it a lovable looking chick."

The location of such a large colony seemed of importance, especially with the early evidence of dry-land nesting, so I looked up the Museum annual reports for 1928 and 1929, seeking clues. The 1928 collecting party was at Rush Lake, but listed only three grebe species, the Pied-billed, Eared and Horned, among 88 species of birds noted. The 1929 camp was near Val Marie and included only Horned and Eared Grebes among 75 bird species. I therefore wrote to the late Fred G. Bard on 10 May 1982 to ask whether he could help in the location of the 900nest colony. Bard's undated reply to my query was as follows:

"I am inclined to think the Western Grebes were at Isle of Bays on Old Wives
Lake as Bradshaw visited Hugh McCrae a keen birder, fairly often." Bradshaw tha year must have visited the Isle of Bay (1.75 mi. long, ${ }^{4}$ and $4 \mathrm{mi}$. out in the lakı from McCrae's ranch) without McCrae. It 1982 Hugh McCrae, retired in Saskatoor and a regular attender of Saskatoor Natural History Society meetings, had nc recollection of visiting such a large con gregation of grebes.

McCrae told me that H. Hedle Mitchell of the Provincial Museum it Regina had once spent a month at hi ranch on SW 6-14-28-W2nd, on the east ern shore of Old Wives Lake, 6 mi. wes and $2 \mathrm{mi}$. north of the hamlet o Crestwynd. Fred Bradshaw, Game Com missioner and later Museum Director often came for a weekend, and onc drove around Old Wives Lake by car, difficult journey, using available road and back trails. Other naturalist visitors to the McCrae ranch included collecto Cyril Guy Harrold in May 1922, Nei Gilmour of Moose Jaw, and Ashley Hin of the Field Museum of Natural History Chicago, in 1925.

McCrae's father, Thomas, had taken Mr. Flickinger, photographer with the For Film Company, to the Isle of Bays in 1919 to make a movie entitled "Bird City," bu" the main bird colony on the island was then the American White Pelican. On another occasion Thomas McCrae had taken Fred Bradshaw, then Game Commissioner, to the island. Hugh himself had visited the island in 1920 with the Banff photographer, Byron Harmon.

Hugh McCrae had a scientific collecting permit so that he could collect unusual species, such as Dickcissel, for the 
museum, from about 1925 to 1940, when he left the ranch for a position as assessor with the Department of Municipal Affairs. He retired in 1968 and regularly attended the meetings of the Saskatoon Natural History Society. He died on 21 August 1986.

Fortunately, there are definite numbers for the Western Grebe colony on the Isle of Bays for 4 other years: 300 pairs in 1928, 64 nests in 1953, 48 nests in 1956 , and 250 nests in 1957. In the latter 2 years they again nested on dry land. The 900 nests in 1929 reported by Bradshaw clearly are an all-time record number for dry-land nests of the Western Grebe anywhere.
BRADSHAW, F. 1929. From Saskatchewan. Oologist 46:93-94.

KNIGHT, L.M. 1967. Birds of the Moose Jaw. Area. Moose Jaw: Moose Jaw Natural History Society. 73 pp.

${ }^{3}$ LAHRMAN, F.W. 1957. Birds of the Isle of Bays, 1957. Blue Jay 15:106-112.

4 NERO, R.W. 1958. Dry-land nest-site of a Western Grebe colony. Auk 75:347-349.

5 NERO, R.W. 1959. Western Grebe colony. Natural History 68:291-294.

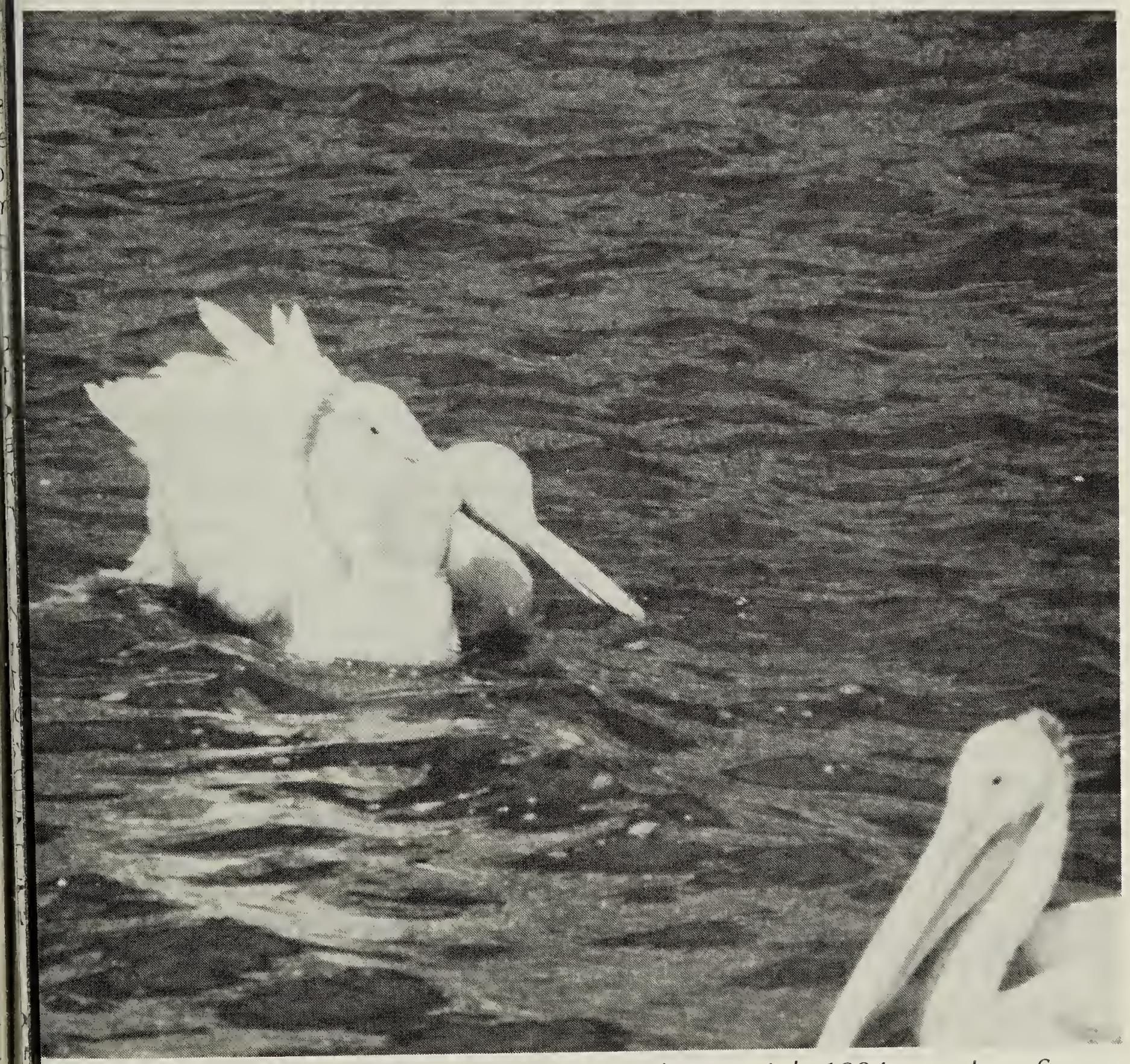

American White Pelican with abnormal bill, Saskatoon, July 1984

Jerry Savage 